\title{
Prauserella salsuginis sp. nov., Prauserella flava sp. nov., Prauserella aidingensis sp. nov. and Prauserella sediminis sp. nov., isolated from a salt lake
}

\section{Correspondence \\ Wen-Jun Li \\ wjli@ynu.edu.cn}

\author{
Yan Li, ${ }^{1} \dagger$ Shu-Kun Tang, ${ }^{1} \dagger$ Yi-Guang Chen, ${ }^{2}$ Jin-Yuan Wu, ${ }^{1}$ \\ Xiao-Yang Zhi, ${ }^{1}$ Yu-Qin Zhang ${ }^{3}$ and Wen-Jun $\mathrm{Li}^{1,4}$
}

\footnotetext{
${ }^{1}$ The Key Laboratory for Microbial Resources of the Ministry of Education, PR China, and Laboratory for Conservation and Utilization of Bio-resources, Yunnan Institute of Microbiology, Yunnan University, Kunming, Yunnan 650091, PR China

${ }^{2}$ College of Biology and Environmental Sciences, Jishou University, Jishou, Hunan 416000, PR China

${ }^{3}$ Institute of Medicinal Biotechnology, Chinese Academy of Medical Sciences \& Peking Union Medical College, Beijing 100050, PR China

${ }^{4}$ Guangdong Key Laboratory of Marine Materia Medica, South China Sea Institute of Oceanology, Chinese Academy of Sciences, Guangzhou 510301, PR China
}

The genus Prauserella was first established by Kim \& Goodfellow (1999) with a species that once belonged to the genera Nocardia (Di Marco \& Spalla, 1957) and Amycolatopsis (Lechevalier et al., 1986). Subsequently, it was emended by $\mathrm{Li}$ et al. (2003) with respect to morphology and the chemical composition of cell constituents. At the time of writing, the genus comprised three species with validly published names: Prauserella rugosa

†These authors contributed equally to this work.

Abbreviation: ISP, International Streptomyces Project.

The GenBank/EMBL/DDBJ accession numbers for the 16S rRNA gene sequences of strains ${\mathrm{YIM} 90625^{\top} \text {, YIM 90630 }}^{\top}$, YIM $90636^{\top}$ and $\mathrm{YIM}$ 90694 ${ }^{\top}$ are FJ444992, FJ444993, FJ444994 and FJ444995, respectively.

Scanning electron micrographs of cells of the four strains and tables showing their culture characteristics and menaquinone and fatty acid compositions are available as supplementary material with the online version of this paper.
(Kim \& Goodfellow, 1999), Prauserella halophila and Prauserella alba (Li et al., 2003). Members of this genus are aerobic, Gram-positive, non-acid-fast and halophilic or halotolerant. Substrate mycelia fragment into irregular rod-shaped elements and aerial mycelia form spores in chains. Hydrolysates of whole cells contain meso-diaminopimelic acid and major amounts of galactose and arabinose (some strains also ribose). MK-9 $\left(\mathrm{H}_{4}\right)$ is the predominant menaquinone. The DNA G+C contents are 65.8-69.9\% (Kim \& Goodfellow, 1999; Li et al., 2003).

Strains YIM $90625^{\mathrm{T}}$, YIM $90630^{\mathrm{T}}$, YIM $90636^{\mathrm{T}}$ and YIM $90694^{\mathrm{T}}$ were isolated from water from Aiding Lake, a salt lake in Xinjiang province, north-west China $\left[89^{\circ} 10^{\prime} 32^{\prime \prime} \mathrm{E}\right.$ $42^{\circ} 32^{\prime} 10^{\prime \prime} \mathrm{N}$; containing $\left(\mathrm{l}^{-1}\right): 127.7648 \mathrm{~g} \mathrm{Na}^{+}, 529.1 \mathrm{mg}$ $\mathrm{K}^{+}, 597.8 \mathrm{mg} \mathrm{Mg}^{2+}, 151.9 \mathrm{mg} \mathrm{Ca}{ }^{2+}, 177.5295 \mathrm{~g} \mathrm{Cl}^{-}$, $29.6352 \mathrm{~g} \mathrm{SO}_{4}^{2-}$ and $200.1 \mathrm{mg} \mathrm{HCO}_{3}{ }^{-}$as the major ions]. Cultured isolates were obtained after 3 weeks of incubation at $37{ }^{\circ} \mathrm{C}$ on cellulose-casein multi-salt medium, described 
by Tang et al., (2008). The colony colour of strain YIM $90636^{\mathrm{T}}$ was white, whereas the colonies of strains YIM $90625^{\mathrm{T}}$, YIM $90630^{\mathrm{T}}$ and YIM $90694^{\mathrm{T}}$ appeared as pale yellow to orange-yellow on the isolation plates. The isolates were maintained at $4{ }^{\circ} \mathrm{C}$ on slants of International Streptomyces Project (ISP) medium 2 agar (Shirling \& Gottlieb, 1966) containing $10 \%(\mathrm{w} / \mathrm{v}) \mathrm{NaCl}$ and as suspensions of mycelial fragments in glycerol $(20 \%$, v/v). Biomass for chemical and molecular studies was obtained by cultivation in shaken flasks (about 150 r.p.m.) using ISP 2 (containing $10 \%, \mathrm{w} / \mathrm{v}, \mathrm{NaCl} ; \mathrm{pH} 7.0$ ) at $37{ }^{\circ} \mathrm{C}$ for 2 weeks.

Morphology was observed by light microscopy (BH2; Olympus) and scanning electron microscopy (JSM5600LV; JEOL) after growth for 28 days on ISP 2 agar containing $10 \%(\mathrm{w} / \mathrm{v}) \mathrm{NaCl}$. Cultural characteristics were examined using standard growth media (Shirling \& Gottlieb, 1966). All media were supplemented with $10 \%$ $(\mathrm{w} / \mathrm{v}) \mathrm{NaCl}$. The colours of substrate and aerial mycelia and any soluble pigments were determined by comparison with chips from the ISCC-NBS colour charts (Kelly, 1964). For all four strains, substrate mycelia were well developed and fragmented. Spore chains were borne on aerial mycelia and cells were non-motile. Strain YIM $90630^{\mathrm{T}}$ did not produce aerial mycelia or spores on any of the media tested (Supplementary Fig. S1, available in IJSEM Online). The four isolates could be distinguished from each other by using a battery of cultural characteristics (Supplementary Table S1, available in IJSEM Online).

Growth at various temperatures $(4,10,15,20,28,37,40$, $45,50,55,60$ and $65{ }^{\circ} \mathrm{C}$ ) was tested on ISP 2 agar containing $10 \%(\mathrm{w} / \mathrm{v}) \mathrm{NaCl}$. Tests for tolerance to $\mathrm{NaCl}$ concentrations and $\mathrm{pH}$ used ISP 2 as the basal medium. Growth with different $\mathrm{NaCl}$ concentrations was tested in the range $0-20 \%(\mathrm{w} / \mathrm{v})$, in increments of $1 \%$. Growth at various $\mathrm{pH}$ values was tested for the range $\mathrm{pH}$ 5.0-10.0, in increments of $0.5 \mathrm{pH}$ units, using the following buffer system: $\mathrm{pH} 5.0,0.1 \mathrm{M}$ citric acid/0.1 M sodium citrate; pH 6.0-8.0, 0.1 M KH $\mathrm{KH}_{4} / 0.1 \mathrm{M} \mathrm{NaOH}$; and $\mathrm{pH} 9.0$ 10.0, $0.1 \mathrm{M} \mathrm{NaHCO} / 2.1 \mathrm{M} \mathrm{Na}_{2} \mathrm{CO}_{3}$. Media and procedures for the determination of physiological features and carbon source utilization patterns were those described by Williams et al. (1983). The detailed morphological and physiological properties of the four strains are given in the species descriptions. The four isolates could be distinguished from each other and from the other type strains of the genus Prauserella by means of morphological and physiological properties (Table 1).

Isomers of diaminopimelic acid and whole-cell sugars were analysed according to Hasegawa et al. (1983). Polar lipids were extracted and examined by two-dimensional TLC and identified using described procedures (Minnikin et al., 1984). Menaquinones were isolated according to Minnikin et al. (1984) and separated by HPLC (Kroppenstedt, 1982). Cellular fatty acids were analysed as described by Sasser (1990) using the Microbial Identification System (MIDI). All four strains, as well as two Prauserella reference strains, P. halophila YIM $90001^{\mathrm{T}}$ and P. alba YIM $90005^{\mathrm{T}}$, contained meso-diaminopimelic acid as the diagnostic diamino acid, and galactose, arabinose and ribose as the major whole-cell sugars. The phospholipids for all four

Table 1. Phenotypic characteristics that differentiate the four isolates from each other and other type strains of the genus Prauserella

Strains: 1, YIM $90625^{\mathrm{T}}$ (P. salsuginis sp. nov.); 2, YIM $90630^{\mathrm{T}}$ (P. flava sp. nov.); 3, YIM $90636^{\mathrm{T}}$ (P. aidingensis sp. nov.); 4, YIM $90694^{\mathrm{T}}(P$. sediminis sp. nov.); 5, P. halophila YIM $90001^{\mathrm{T}} ; 6$, P. alba YIM $90005^{\mathrm{T}} ; 7$, P. rugosa DSM $43194^{\mathrm{T}}$. Data in columns $1-4$ were from this study, in columns 5 and 6 from Li et al. (2003) and column 7 from Kim \& Goodfellow (1999) and Li et al. (2003). +, Positive; -, negative.

\begin{tabular}{|c|c|c|c|c|c|c|c|}
\hline Characteristic & 1 & 2 & 3 & 4 & 5 & 6 & 7 \\
\hline Aerial mycelium & + & - & + & + & + & + & - \\
\hline \multicolumn{8}{|l|}{ Growth with $\mathrm{NaCl}(\%, w / v)$} \\
\hline Range & $5-15$ & $5-15$ & $5-15$ & $5-20$ & $5-25$ & $0-25$ & $0-20$ \\
\hline Optimum & $8-10$ & $8-10$ & $8-10$ & 10 & $10-15$ & $10-15$ & $5-10$ \\
\hline Degradation of urea & - & - & - & - & + & - & - \\
\hline \multicolumn{8}{|l|}{ Carbon utilization } \\
\hline L-Arabinose & + & - & - & - & - & + & + \\
\hline D-Galactose & + & - & - & - & - & + & + \\
\hline myo-Inositol & + & - & - & - & + & + & - \\
\hline Maltose & - & - & - & - & - & + & + \\
\hline Trehalose & + & - & + & - & + & - & + \\
\hline \multicolumn{8}{|l|}{ Nitrogen utilization } \\
\hline L-Arginine & - & - & - & + & + & + & - \\
\hline L-Glycine & - & - & - & - & + & + & + \\
\hline L-Lysine & + & + & - & + & + & + & - \\
\hline L-Serine & - & - & - & - & + & + & - \\
\hline DNA G $+\mathrm{C}$ content $(\mathrm{mol} \%)$ & 69.1 & 69.9 & 70.1 & 69.1 & 65.8 & 66.7 & $69.2^{*}$ \\
\hline
\end{tabular}

${ }^{\star}$ Data from this study. 
isolates comprised phosphatidylmethylethanolamine, phosphatidylcholine, phosphatidylinositol, phosphatidylglycerol, diphosphatidylglycerol and some unknown phospholipids. The detailed menaquinone compositions and fatty acid profiles are given in Supplementary Tables S2 and S3 (in IJSEM Online), respectively. The predominant menaquinone was MK- $9\left(\mathrm{H}_{4}\right)$, but minor amounts of other menaquinones differentiated the strains from each other. The chemotaxonomic data for the four strains were consistent with their assignment to the genus Prauserella (Kim \& Goodfellow, 1999; Li et al., 2003).

For the determination of the DNA G+C content, the genomic DNA of the four strains were prepared according to the method of Marmur (1961) and the DNA G+C contents were determined by reversed-phase HPLC according to Mesbah et al. (1989). The G +C contents of the genomic DNA of strains YIM $90625^{\mathrm{T}}$, YIM $90630^{\mathrm{T}}$, YIM $90636^{\mathrm{T}}$ and YIM $90694^{\mathrm{T}}$ were 69.1, 69.9, 70.1 and $69.1 \mathrm{~mol} \%$, respectively.

Extraction of genomic DNA and PCR amplification of the $16 \mathrm{~S}$ rRNA gene sequence were performed as described by Li et al. (2007). Multiple alignments with sequences from Prauserella species and other closely related species and calculation of levels of sequence similarity were carried out using the EzTaxon server version 2.0 (Chun et al., 2007). Phylogenetic analyses were performed using three treemaking algorithms: neighbour-joining (Saitou \& Nei, 1987), maximum-likelihood (Felsenstein, 1981) and maximum-parsimony (Fitch, 1971) methods. A phylogenetic tree was constructed using the neighbour-joining method of Saitou \& Nei (1987) from $K_{\text {nuc }}$ values (Kimura, 1980) using MEGA version 4.0 (Tamura et al., 2007). The topology of the phylogenetic tree was evaluated by using the bootstrap resampling method of Felsenstein (1985) with 1000 replicates.
The almost-complete 16S rRNA gene sequences of strains YIM $90625^{\mathrm{T}}(1430 \mathrm{bp})$, YIM $90630^{\mathrm{T}}(1457 \mathrm{bp})$, YIM $90636^{\mathrm{T}}$ (1455 bp) and YIM $90694^{\mathrm{T}}$ (1465 bp) were determined. These sequences were analysed by preliminary comparison with sequences from the GenBank database and the results indicated that the four isolates were most closely related to members of the genus Prauserella. Phylogenetic analysis showed that strains YIM $90625^{\mathrm{T}}$, YIM $90630^{\mathrm{T}}$ and YIM $90694^{\mathrm{T}}$ fell into one distinct subclade with $P$. alba YIM $90005^{\mathrm{T}}$ and that strain YIM $90636^{\mathrm{T}}$ fell into a separate subclade between $P$. alba YIM $90005^{\mathrm{T}}$ and P. halophila YIM $90001^{\mathrm{T}}$ (Fig. 1). The four strains showed 16S rRNA gene sequence similarities higher than $98 \%$ with each other and with P. alba YIM $90005^{\mathrm{T}}$ and P. halophila YIM $90001^{\mathrm{T}}$ (Table 2).

DNA-DNA hybridization studies were performed using the optical renaturation method (De Ley et al., 1970; Huß et al., 1983; Jahnke, 1992) between the four isolates and $P$. alba YIM $90005^{\mathrm{T}}$ and P. halophila YIM $90001^{\mathrm{T}}$. DNA-DNA relatedness values ranged from 20.8 to $60.3 \%$ (mean values from three replicate hybridizations; Table 2), which were lower than the threshold value of $70 \%$ recommended by Wayne et al., (1987) for the delineation of genomic species. On the basis of these results, the isolates represent four novel species of the genus Prauserella.

Additionally, the four isolates could be distinguished from each other and from the two most closely related Prauserella species, P. halophila and P. alba, on the basis of physiological and biochemical characteristics and chemotaxonomic data (Table 1 and Supplementary Tables S1-S3). Based on the results of the phenotypic and genotypic analyses, we consider that strains YIM $90625^{\mathrm{T}}$, YIM $90630^{\mathrm{T}}$, YIM $90636^{\mathrm{T}}$ and YIM $90694^{\mathrm{T}}$ each represent a novel species of the genus Prauserella, for which the names proposed are Prauserella salsuginis sp. nov.,

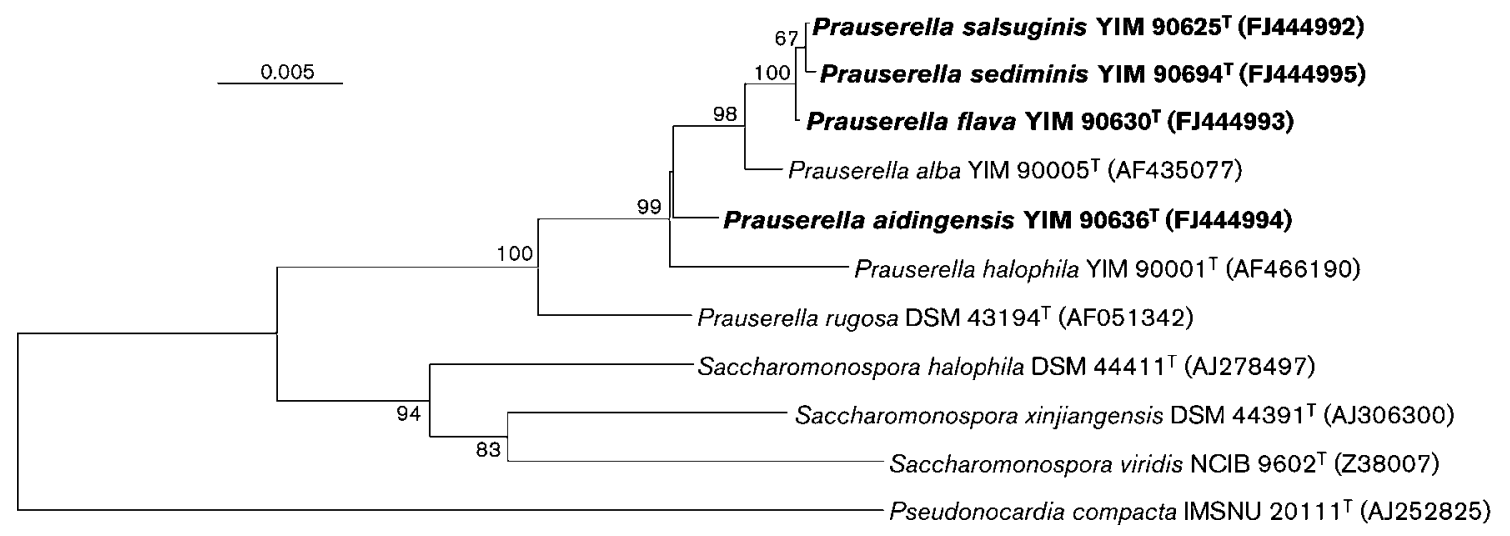

Fig. 1. Phylogenetic tree based on $16 \mathrm{~S}$ rRNA gene sequence analysis, constructed from evolutionary distances with the

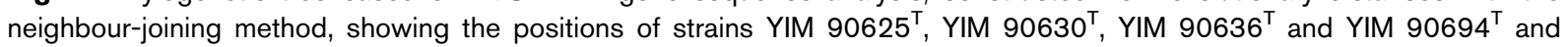
related taxa. Bootstrap values $(>50 \%)$ based on 1000 replicates are shown at branch nodes. Pseudonocardia compacta IMSNU $20111^{\top}$ was used as the outgroup. Bar, $0.5 \%$ sequence divergence. 
Table 2. DNA-DNA relatedness and $16 \mathrm{~S}$ rRNA gene sequence similarity values (\%) between the four novel strains and their two closest relatives

Values in parentheses are $16 \mathrm{~S}$ rRNA gene sequence similarity values.

\begin{tabular}{|c|c|c|c|c|c|c|}
\hline Strains & 1 & 2 & 3 & 4 & 5 & 6 \\
\hline 1. P. halophila YIM $90001^{\mathrm{T}}$ & $100(100)$ & & & & & \\
\hline 2. P. alba YIM $90005^{\mathrm{T}}$ & $30.20(98.5)$ & $100(100)$ & & & & \\
\hline 3. P. salsuginis sp. nov. YIM $90625^{\mathrm{T}}$ & $20.80(98.3)$ & $47.15(99.5)$ & $100(100)$ & & & \\
\hline 4. P. flava sp. nov. YIM $90630^{\mathrm{T}}$ & $41.25(98.3)$ & $43.60(99.6)$ & $56.90(99.9)$ & $100(100)$ & & \\
\hline 5. $P$. aidingensis sp. nov. YIM $90636^{\mathrm{T}}$ & $53.65(98.9)$ & $41.40(99.2)$ & $43.95(99.0)$ & $55.30(99.3)$ & $100(100)$ & \\
\hline 6. $P$. sediminis sp. nov. YIM $90694^{\mathrm{T}}$ & $45.20(98.3)$ & $51.60(99.5)$ & $60.25(99.9)$ & $40.90(99.9)$ & $47.90(99.2)$ & $100(100)$ \\
\hline
\end{tabular}

Prauserella flava sp. nov., Prauserella aidingensis sp. nov. and Prauserella sediminis sp. nov., respectively.

\section{Description of Prauserella salsuginis sp. nov.}

Prauserella salsuginis (sal.su'gi.nis. L. gen. n. salsuginis of salt water, from which the type strain was isolated).

Aerobic, Gram-positive, non-acid-fast and non-motile. Aerial mycelium is white and substrate mycelium is fragmented. Colony colours are light grey-white (ISP 5), brilliant yellow (ISP 2), deep yellow (Czapek's agar) and pale orange-yellow (potato agar and nutrient agar). Optimum growth occurs on ISP 2 agar supplemented with $8-10 \% \mathrm{NaCl}$ at $28-37{ }^{\circ} \mathrm{C}$ and $\mathrm{pH} 7.0$. Temperature, $\mathrm{pH}$ and $\mathrm{NaCl}$ tolerance ranges are $15-45{ }^{\circ} \mathrm{C}, \mathrm{pH}$ 6.0-9.0 and $5-15 \%(\mathrm{w} / \mathrm{v}) \mathrm{NaCl}$, respectively. L-Arabinose, cellobiose, D-fructose, D-galactose, D-glucose, myo-inositol, lactose, D-mannitol, D-mannose, L-rhamnose, D-ribose, trehalose, D-xylitol and D-xylose are utilized as sole carbon sources, but maltose and raffinose are not. L-Alanine, Lhistidine, L-hydroxyproline, L-lysine, L-phenylalanine, Lproline, threonine, DL-tryptophan, L-tyrosine, L-xanthine and L-valine are utilized as sole nitrogen sources, but adenine, L-arginine, glycine, DL-methionine and L-serine are not. Milk coagulation, gelatin liquefaction and catalase are positive, but $\mathrm{H}_{2} \mathrm{~S}$ and melanin production, starch hydrolysis, urease, nitrate reduction and oxidase are negative. The DNA $\mathrm{G}+\mathrm{C}$ content of the type strain is $69.1 \mathrm{~mol} \%$.

The type strain, YIM $90625^{\mathrm{T}}\left(=\mathrm{CCTCC}\right.$ AA $208051^{\mathrm{T}}=$ DSM $45264^{\mathrm{T}}$ ), was isolated from Aiding Lake, a salt lake in Xinjiang province, north-west China.

\section{Description of Prauserella flava sp. nov.}

Prauserella flava (fla'va. L. fem. adj. flava yellow, referring to the colour of the substrate mycelium).

Aerobic, Gram-positive, non-acid-fast, non-motile organism. Aerial mycelium and spores are not produced on any of the media tested and substrate mycelium is fragmented. Colony colours are light yellow (ISP 5), brown (ISP 3), brilliant yellow (ISP 2) and grey-yellow-white (potato agar). Optimum growth occurs on ISP 2 agar supplemen- ted with $8-10 \% \mathrm{NaCl}$ at $28-37{ }^{\circ} \mathrm{C}$ and $\mathrm{pH} 7.0$. Temperature, $\mathrm{pH}$ and $\mathrm{NaCl}$ tolerance ranges are 15$45^{\circ} \mathrm{C}, \mathrm{pH}$ 6.0-9.0 and 5-15\% (w/v) $\mathrm{NaCl}$, respectively. DFructose, D-glucose, lactose, D-ribose and D-xylose are utilized as sole carbon sources, but L-arabinose, cellobiose, D-galactose, myo-inositol, maltose, D-mannitol, D-mannose, raffinose, L-rhamnose, trehalose and D-xylitol are not. L-Alanine, L-histidine, L-hydroxyproline, L-lysine, L-phenylalanine, L-proline, threonine, DL-tryptophan, L-tyrosine, L-xanthine and L-valine are utilized as sole nitrogen sources, but adenine, L-arginine, L-glycine, DL-methionine and L-serine are not. Milk coagulation, gelatin liquefaction and catalase are positive, but $\mathrm{H}_{2} \mathrm{~S}$ production, starch hydrolysis, urease, nitrate reduction and oxidase are negative. The DNA $\mathrm{G}+\mathrm{C}$ content of the type strain is $69.9 \mathrm{~mol} \%$.

The type strain, YIM $90630^{\mathrm{T}}\left(=\right.$ CCTCC AA $208052^{\mathrm{T}}=$ DSM $45265^{\mathrm{T}}$ ), was isolated from Aiding Lake, a salt lake in Xinjiang province, north-west China.

\section{Description of Prauserella aidingensis sp. nov.}

Prauserella aidingensis (ai.ding.en'sis. N.L. fem. adj. aidingensis from Aiding Lake, where the type strain was isolated).

Aerobic, Gram-positive, non-acid-fast, non-motile organism. Aerial mycelium is white and substrate mycelium is fragmented. Colony colours are light grey-white (ISP 5), slight grey-white (ISP 3), brilliant yellow (ISP 2) and brilliant yellow (potato agar). Optimum growth occurs on ISP 2 medium supplemented with $8-10 \% \mathrm{NaCl}$ at $28-$ $37{ }^{\circ} \mathrm{C}$ and $\mathrm{pH}$ 7.0. Temperature, $\mathrm{pH}$ and $\mathrm{NaCl}$ tolerance ranges are $15-45^{\circ} \mathrm{C}, \mathrm{pH}$ 6.0-9.0 and 5-15\% (w/v) $\mathrm{NaCl}$, respectively. D-Fructose, D-glucose, lactose, L-rhamnose, Dribose, trehalose and D-xylose are utilized as sole carbon sources, but L-arabinose, cellobiose, D-galactose, myoinositol, maltose, D-mannitol, D-mannose, raffinose and D-xylitol are not. L-Alanine, L-histidine, L-hydroxyproline, L-phenylalanine, L-proline, threonine, DL-tryptophan, Ltyrosine, L-xanthine and L-valine are utilized as sole nitrogen sources, but adenine, L-arginine, L-glycine, Llysine, DL-methionine and L-serine are not. Milk coagulation, gelatin liquefaction and catalase are positive, but 
$\mathrm{H}_{2} \mathrm{~S}$ production, starch hydrolysis, urease, nitrate reduction and oxidase are negative. The DNA G $+\mathrm{C}$ content of the type strain is $70.1 \mathrm{~mol} \%$.

The type strain, YIM $90636^{\mathrm{T}}$ (=CCTCC AA $208053^{\mathrm{T}}=$ DSM $45266^{\mathrm{T}}$ ), was isolated from Aiding Lake, a salt lake in Xinjiang province, north-west China.

\section{Description of Prauserella sediminis sp. nov.}

Prauserella sediminis (se.di'mi.nis. L. gen. n. sediminis of sediment).

Aerobic, Gram-positive, non-acid-fast, non-motile organism. Aerial mycelium is white on most media tested and substrate mycelium is fragmented. Colony colours are deep grey-white (ISP 5), pale yellow (ISP 3), orange-yellow (ISP 2) and grey reddish orange (potato agar). Optimum growth occurs on ISP 2 medium supplemented with $10 \% \mathrm{NaCl}$ at $28-37{ }^{\circ} \mathrm{C}$ and $\mathrm{pH}$ 7.0. Temperature, $\mathrm{pH}$ and $\mathrm{NaCl}$ tolerance ranges are $15-45^{\circ} \mathrm{C}, \mathrm{pH} 6.0-9.0$ and 5$20 \%(\mathrm{w} / \mathrm{v}) \mathrm{NaCl}$, respectively. D-Glucose, lactose and Lrhamnose are utilized as sole carbon sources, but Larabinose, cellobiose, D-fructose, D-galactose, myo-inositol, maltose, D-mannitol, D-mannose, raffinose, D-ribose, trehalose, D-xylitol and D-xylose are not. L-Alanine, Larginine, L-histidine, L-lysine, L-hydroxyproline, L-phenylalanine, L-proline, threonine, DL-tryptophan, L-tyrosine, Lxanthine and L-valine are utilized as sole nitrogen sources, but adenine, L-glycine, DL-methionine and L-serine are not. Milk coagulation, gelatin liquefaction and catalase are positive, but $\mathrm{H}_{2} \mathrm{~S}$ production, starch hydrolysis, urease, nitrate reduction and oxidase are negative. The DNA G + C content of the type strain is $69.1 \mathrm{~mol} \%$.

The type strain, YIM $90694^{\mathrm{T}}\left(=\right.$ CCTCC AA $208054^{\mathrm{T}}=$ DSM $45267^{\mathrm{T}}$ ), was isolated from Aiding Lake, a salt lake in Xinjiang province, north-west China.

\section{Acknowledgements}

This research was supported by the National Basic Research Program of China (no. 2010CB833800), the National Natural Science Foundation of China (nos. 30600001, 30860002, 30870005), Key Project of International Cooperation (2007DFB31620) and Yunnan Provincial Science and Technology Department (nos. 2009AC017, 2009DA002).

\section{References}

Chun, J., Lee, J.-H., Jung, Y., Kim, M., Kim, S., Kim, B. K. \& Lim, Y. W. (2007). EzTaxon: a web-based tool for the identification of prokaryotes based on $16 \mathrm{~S}$ ribosomal RNA gene sequences. Int J Syst Evol Microbiol 57, 2259-2261.

De Ley, J., Cattoir, H. \& Reynaerts, A. (1970). The quantitative measurement of DNA hybridization from renaturation rates. Eur $J$ Biochem 12, 133-142.

Di Marco, A. \& Spalla, C. (1957). La produzione di cobalamine da fermentazione con una nuova specie di Nocardia: Nocardia rugosa. Giorn Microbiol 4, 24-30 (in Italian).
Felsenstein, J. (1981). Evolutionary trees from DNA sequences: a maximum likelihood approach. J Mol Evol 17, 368-376.

Felsenstein, J. (1985). Confidence limits on phylogenies: an approach using the bootstrap. Evolution 39, 783-791.

Fitch, W. M. (1971). Toward defining the course of evolution: minimum change for a specific tree topology. Syst Zool 20, 406-416.

Hasegawa, T., Takizawa, M. \& Tanida, S. (1983). A rapid analysis for chemical grouping aerobic actinomycetes. J Gen Appl Microbiol 29, 319-322.

Huß, V. A. R., Festl, H. \& Schleifer, K. H. (1983). Studies on the spectrophotometric determination of DNA hybridization from renaturation rates. Syst Appl Microbiol 4, 184-192.

Jahnke, K. D. (1992). BASIC computer program for evaluation of spectroscopic DNA renaturation data from GILFORD SYSTEM 2600 spectrophotometer on a $\mathrm{PC} / \mathrm{XT} / \mathrm{AT}$ type personal computer. J Microbiol Methods 15, 61-73.

Kelly, K. L. (1964). Inter-Society Color Council - National Bureau of Standards Color Name Charts Illustrated with Centroid Colors. Washington, DC: US Government Printing Office.

Kim, S. B. \& Goodfellow, M. (1999). Reclassification of Amycolatopsis rugosa Lechevalier et al. 1986 as Prauserella rugosa gen. nov., comb. nov. Int J Syst Bacteriol 49, 507-512.

Kimura, M. (1980). A simple method for estimating evolutionary rates of base substitutions through comparative studies of nucleotide sequence. J Mol Evol 16, 111-120.

Kroppenstedt, R. M. (1982). Separation of bacterial menaquinones by HPLC using reverse phase (RP18) and a silver loaded ion exchanger as stationary phases. J Liq Chromatogr 5, 2359-2367.

Lechevalier, M. P., Prauser, H., Labeda, D. P. \& Ruan, J.-S. (1986). Two new genera of nocardioform actinomycetes: Amycolata gen. nov. and Amycolatopsis gen. nov. Int J Syst Bacteriol 36, 29-37.

Li, W.-J., Xu, P., Tang, S.-K., Xu, L.-H., Kroppenstedt, R.-M., Stackebrandt, E. \& Jiang, C.-L. (2003). Prauserella halophila sp. nov. and Prauserella alba sp. nov., moderately halophilic actinomycetes from saline soil. Int J Syst Evol Microbiol 53, 1545-1549.

Li, W. J., Xu, P., Schumann, P., Zhang, Y. O., Pukall, R., Xu, L. H., Stackebrandt, E. \& Jiang, C. L. (2007). Georgenia ruanii sp. nov., a novel actinobacterium isolated from forest soil in Yunnan (China) and emended description of the genus Georgenia. Int J Syst Evol Microbiol 57, 1424-1428.

Marmur, J. (1961). A procedure for the isolation of deoxyribonucleic acid from microorganisms. J Mol Biol 3, 208-218.

Mesbah, M., Premachandran, U. \& Whitman, W. B. (1989). Precise measurement of the $\mathrm{G}+\mathrm{C}$ content of deoxyribonucleic acid by highperformance liquid chromatography. Int J Syst Bacteriol 39, 159-167.

Minnikin, D. E., O'Donnell, A. G., Goodfellow, M., Alderson, G., Athalye, M., Schaal, A. \& Parlett, J. H. (1984). An integrated procedure for the extraction of bacterial isoprenoid quinones and polar lipids. J Microbiol Methods 2, 233-241.

Saitou, N. \& Nei, M. (1987). The neighbor-joining method: a new method for reconstructing phylogenetic trees. Mol Biol Evol 4, 406425.

Sasser, M. (1990). Identification of bacteria by gas chromatography of cellular fatty acids. USFCC Newsl 20, 16.

Shirling, E. B. \& Gottlieb, D. (1966). Methods for characterization of Streptomyces species. Int J Syst Bacteriol 16, 313-340.

Tamura, K., Dudley, J., Nei, M. \& Kumar, S. (2007). MEGA4: Molecular Evolutionary Genetics Analysis (MEGA) software version 4.0. Mol Biol Evol 24, 1596-1599.

Tang, S.-K., Tian, X.-P., Zhi, X.-Y., Cai, M., Wu, J.-Y., Yang, L.-L., Xu, L.-H. \& Li, W.-J. (2008). Haloactinospora alba gen. nov., sp. nov., a 
halophilic filamentous actinomycete of the family Nocardiopsaceae. Int J Syst Evol Microbiol 58, 2075-2080.

Wayne, L. G., Brenner, D. J., Colwell, R. R., Grimont, P. A. D., Kandler, O., Krichevsky, M. I., Moore, L. H., Moore, W. E. C., Murray, R. G. E. \& other authors (1987). International Committee on Systematic Bacteriology. Report of the ad hoc committee on reconciliation of approaches to bacterial systematics. Int J Syst Bacteriol 37, 463-464.

Williams, S. T., Goodfellow, M., Alderson, G., Wellington, E. M. H., Sneath, P. H. A. \& Sackin, M. J. (1983). Numerical classification of Streptomyces and related genera. J Gen Microbiol 129, 17431813. 